DOI: $10.19195 / 0137-1134.114 .9$

\author{
WITOLD MAŁECKI \\ Uniwersytet Wrocławski \\ witold.malecki@uwr.edu.pl
}

\title{
PRAWO ADMINISTRACYJNE PRYWATNE. PROPOZYCJA NOWEGO TERMINU W SIATCE POJECCIOWEJ POLSKIEGO PRAWA ADMINISTRACYJNEGO
}

\begin{abstract}
Abstrakt: Wyróżnienie zbioru norm nazwanego „prawem administracyjnym prywatnym” warunkowane jest uznaniem, że twierdzeniu o publicznoprawnej przynależności prawa administracyjnego należy przypisać walor typologiczny, nie zaś klasyfikacyjny — w każdej gałęzi prawa (również w prawie administracyjnym) można bowiem wyodrębnić, w różnych proporcjach, normy o charakterze publicznoprawnym i prywatnoprawnym. Normy prawa administracyjnego prywatnego wyznaczają prawne ramy posługiwania się przez administrację publiczną formami działania właściwymi tradycyjnie prawu prywatnemu w sposób uniemożliwiający „ucieczkę do prawa prywatnego”, zespalając prywatnoprawne sposoby działania i publicznoprawne mechanizmy ochrony. Jako modelowy obszar regulacji prawnej podlegający zaliczeniu do prawa administracyjnego prywatnego przedstawia się prawo zamówień publicznych.
\end{abstract}

Słowa kluczowe: prawo administracyjne prywatne, ucieczka do prawa prywatnego, prawo zamówień publicznych

Coraz powszechniejsze współcześnie zjawisko posługiwania się przez administrację publiczną formami działania właściwymi tradycyjnie prawu prywatnemu stanowi od dłuższego czasu źródło wyzwań badawczych doktryny prawa administracyjnego ${ }^{1}$. Wyzwania te koncentrują się zarówno wokół problemów dogmatycznoprawnych (na przykład stosowanie przepisów prawa cywilnego do porozumień

1 Wyzwanie to zostało podjęte również na szczeblu legislacyjnym, przez umieszczenie w projekcie ustawy — Przepisy ogólne prawa administracyjnego rozdziału 6, zatytułowanego „Porozumienia i umowy administracyjne". Projekt został wniesiony pod obrady Sejmu VI kadencji w grudniu 2010 r. (druk sejmowy nr 3942). W obecnej kadencji projekt nie jest przedmiotem prac Sejmu. 
komunalnych ${ }^{2}$ ), jak i teoretycznoprawnych, związanych między innymi z usytuowaniem norm regulujących prywatnoprawne formy działania administracji w strukturze poziomej systemu prawa, w szczególności w ramach dychotomii prawo publiczne-prawo prywatne oraz prawo administracyjne-prawo cywilne. Niniejszy artykuł ma na celu sformułowanie propozycji wprowadzenia do siatki pojęciowej prawa administracyjnego terminu zaczerpniętego z doktryny niemieckiej — „prawo administracyjne prywatne”, który — jak się wydaje - może się okazać sposobem przełamania tradycyjnych dychotomii i przyczynkiem do refleksji nad statusem i granicami prawa administracyjnego w systemie prawa.

Sytuowanie prawa administracyjnego w obrębie struktury nazywanej ,prawem publicznym" jest nierzadko ujmowane w literaturze jako jeden z podstawowych wyznaczników charakteryzujących prawo administracyjne ${ }^{3}$. Co więcej, prawo administracyjne bywa przedstawiane jako modelowy, wzorcowy dział prawa publicznego, najbardziej oczywisty przykład gałęzi prawa wymienianych wśród substratów prawa publicznego ${ }^{4}$. Dlatego też termin , prawo administracyjne prywatne", sugerujący rozszczepienie (pozornie) niepodważalnej, aksjomatycznej więzi między kategoriami prawa publicznego i prawa administracyjnego, prima facie może wywoływać pewną konsternację na tle ugruntowanej publicznoprawnej tożsamości prawa administracyjnego. Konsternacji tej sprzyja okoliczność, że koncepcja prawa administracyjnego prywatnego, choć obecna w literaturze zagranicznej, słabo zaznaczyła swoje istnienie w nauce polskiej ${ }^{5}$.

Refleksja nad zasadnością wyróżniania „prawa administracyjnego prywatnego", podejmowana na gruncie nauki polskiej, powinna obejmować ustalenia o charakterze zarówno apriorycznym, jak i aposteriorycznym. Rozważenia natury apriorycznej należy skierować na rozstrzygnięcie zagadnienia, czy w systemie prawa może (hipotetycznie) istnieć zbiór norm, któremu należałoby przypisać

2 Zob. na przykład glosę Z. Leońskiego do wyroku Naczelnego Sądu Administracyjnego Ośrodek Zamiejscowy w Łodzi z dnia 27 września 1994 r., sygn. SA/Łd 1906/94, OSP 1996, poz. 52, s. $127-129$.

${ }^{3}$ Zob. między innymi J. Filipek, Prawo administracyjne. Instytucje ogólne, cz. 1, Kraków 2003, s. 41; J. Boć, [w:] Prawo administracyjne, red. J. Boć, Wrocław 2010, s. 37-40; J. Zimmermann, Prawo administracyjne, Warszawa 2014, s. 41; Z. Duniewska, [w:] System Prawa Administracyjnego, t. 1. Instytucje prawa administracyjnego, red. R. Hauser, Z. Niewiadomski, A. Wróbel, Warszawa 2015, s. 152.

${ }^{4}$ Por. między innymi J. Łętowski, $W$ sprawie granicy między prawem publicznym a prywatnym, [w:] Prace z prawa cywilnego wydane dla uczczenia pracy naukowej Profesora Józefa Stanisława Piątowskiego, red. B. Kordasiewicz, E. Łętowska, Wrocław 1985, s. 357; J. Nowacki, Prawo publiczne - prawo prywatne, Katowice 1992, s. 67.

5 Do nielicznych rodzimych opracowań odwołujących się do kategorii prawa administracyjnego prywatnego należą monografie: P. Stec, Umowy w administracji. Studium cywilnoprawne, Warszawa 2013, s. 13; A. Haręża, M. Szydło, W. Szydło, Współpraca dla rozwoju regionu pomiędzy jednostkami samorządu terytorialnego a przedsiębiorcami geologicznymi i górniczymi, Wrocław 2013, s. 12; J. Zimmermann, Aksjomaty prawa administracyjnego, Warszawa 2013, s. 55; idem, Prawo administracyjne, s. 43. 
nazwę „prawo administracyjne prywatne”. Rozważania te winny koncentrować się w dwóch obszarach — treści i formy. Aprioryczna refleksja nad treścią, materią prawa administracyjnego prywatnego objęłaby próbę rozstrzygnięcia, w którym obszarze systemu prawa (a ściślej rzecz ujmując — na którym odcinku pogranicza prawa administracyjnego i prawa cywilnego) występują zależności skutkujące sprzężeniem pierwiastka administracyjnoprawnego i pierwiastka prywatnoprawnego, odzwierciedlającym się w normach grupowanych en bloc jako prawo administracyjne prywatne. Refleksja nad formą koncentrowałaby się zaś na rozważeniu, czy zasadne byłoby posługiwanie się dla oznaczenia tych norm nazwą , prawo administracyjne prywatne", mogącą budzić wątpliwości - jak zasygnalizowano — ze względu na dogmat o publicznoprawnym statusie i charakterze prawa administracyjnego. Rozważania natury aposteriorycznej, warunkowane pozytywnym rezultatem rozważań apriorycznych, miałyby na celu ustalenie, jakie normy prawa pozytywnego byłyby adekwatne wobec abstrakcyjnie zakreślonego konstruktu „prawa administracyjnego prywatnego" - a zatem jakie normy prawa pozytywnego wypełniłyby teoretycznie zarysowane ramy ${ }^{6}$.

Niniejszy artykuł, co oczywiste, nie pretenduje do miana kompleksowego i wyczerpującego opracowania skomplikowanej problematyki zasadności wyodrębniania kategorii prawa administracyjnego prywatnego. Ma raczej na celu zasygnalizowanie głównych kierunków analizy zagadnienia i przedstawienie podstawowych tez w odniesieniu do przedstawionych powyżej sfer rozważań nad prawem administracyjnym prywatnym — apriorycznej i aposteriorycznej.

Ze względu na śladową ledwie obecność koncepcji prawa administracyjnego prywatnego w literaturze polskiej, aprioryczne rozważania nad płaszczyzną wyodrębniania materii prawa administracyjnego prywatnego należy przeprowadzić na podstawie dorobku nauki zagranicznej, w szczególności — nauki niemieckiej. Refleksja nad prawem administracyjnym prywatnym jest w nauce niemieckiej nierozdzielnie związana z pojęciami „wybór reżimu prawnego" (Rechtsregimewahl) ${ }^{7}$ oraz „ucieczka do prawa prywatnego” (Flucht ins Privatrecht) ${ }^{8}$. Pojęcie „wyboru reżimu prawnego" odnosi się do swobody organów administracji publicznej

${ }^{6}$ Inną strukturę rozważań nad wyodrębnianiem prawa administracyjnego prywatnego przedstawia portugalska autorka A.R. Coxo, wyróżniając cztery wymiary analizy kategorii prawa administracyjnego prywatnego - subiektywny, obiektywny, materialnoprawny i procesowy. Zob. eadem, Direito Administrativo Privado - Contributos para a compreensão do Direito Suis, Lisboa 2016.

7 Zob. E. Schmidt-Aßmann, Ogólne prawo administracyjne jako idea porządku. Założenia i zadania tworzenia systemu prawnoadministracyjnego, przeł. A. Wasilewski, Warszawa 2011, s. 366.

8 Pojęcie sformułowane przez. F. Fleinera, zob. idem, Institutionen des Deutschen Verwaltungsrechts, Tübingen 1928, s. 326. 
w zakresie wyboru publicznoprawnych lub prywatnoprawnych form realizacji zadań administracyjnych ${ }^{9}$. Wybór form prywatnoprawnych nie może prowadzić do „ucieczki do prawa prywatnego" 10 — posługiwanie się instrumentami prawa prywatnego nie sprawia bowiem, że organy administracji publicznej występują jako samoistne podmioty prawa prywatnego korzystające $\mathrm{z}$ autonomii woli i swobody kształtowania stosunków prawnych ${ }^{11}$. Wybór prywatnoprawnych form realizacji zadań administracyjnych nie uchybia bowiem w żadnym stopniu implikacjom wynikającym z art. 1 ust. 3 Konstytucji RFN, który nakłada na władzę ustawodawczą, wykonawczą i sądowniczą powinność stosowania konstytucyjnych praw podstawowych — również w sferze prawa prywatnego organy administracji są w pełnym zakresie podmiotami obowiązków wynikających z praw podstawowych (grundrechtliche Bindungen) ${ }^{12}$.

Obszar związania organów administracji publicznej obowiązkami wynikającymi z praw podstawowych w zakresie posługiwania się instrumentami prawa prywatnego wyznacza płaszczyznę wyodrębniania prawa administracyjnego prywatnego. Pojęcie to nie jest jednak w nauce niemieckiej ujmowane w sposób jednolity. Pierwsze z prezentowanych w literaturze ujęć zakłada sytuowanie prawa administracyjnego prywatnego w sferze stosowania prawa. Prawo administracyjne prywatne nie jest więc postrzegane w sposób statyczny — jako pewien z góry wyabstrahowany zbiór norm prawnych, lecz w sposób dynamiczny — jako zjawisko przenikania się norm prawa prywatnego i norm prawa administracyjnego (służących realizacji praw podstawowych) w działaniach podejmowanych przez organy administracji publicznej w obszarze prawa prywatnego ${ }^{13}$. Jak zaznaczał J. Wipfler, istotą prawa administracyjnego prywatnego ma być ograniczenie zasad prawa prywatnego (takich jak na przykład swoboda umów) zasadami prawa publicznego (takimi jak zasada legalności, zasada równości) ${ }^{14}$. W nauce hiszpańskiej S. González-Varas Ibáñez określił zjawisko prawa administracyjnego prywatnego jako środek zaradczy, lekarstwo (remedio) na negatywne konsekwencje stosowania prawa prywatnego przez administrację publiczną, uniemożliwiające pełną ucieczkę od administracyjnoprawnych determinantów funkcjonowania administracji, nakierowanych na realizację interesu publicznego ${ }^{15}$.

9 H. Maurer, Ogólne prawo administracyjne, przeł. K. Nowacki, Wrocław 2003, s. 43.

10 Zob. A. Katz, Staatsrecht. Grundkurs im öffentlichen Recht, Heidelberg 2010, s. 311.

11 Zob. A.F. Wasiliewa, Dogowor w administratiwnom prawie, [w:] Dogowor w publicznom prawie, red. J.W. Gricenko, J.G. Babieluk, Moskwa 2009, s. 196.

12 R. Stober, Handbuch des Wirtschaftsverwaltungs- und Umweltrechts, Köln 1989, s. 416417.

13 Zob. między innymi D. Schroeder, Grundrechte, Heidelberg 2016, s. 18-19; C. Röder-Persson, Das Privileg der öffentlichen Grundstückslast im Zwangsversteigerungsgesetz im Lichte der Abschaffung des fiskalischen Konkursprivilegs — zugleich eine Abhandlung über die öffentliche Grundstückslast, Berlin 2004, s. 55.

14 J. Wipfler, Leitfaden der Verwaltungslehre, Berlin 1979, s. 91.

15 S. González-Varas Ibáñez, El Derecho administrativo privado, Madrid 1996, s. 123. 
Drugie ujęcie prawa administracyjnego prywatnego zakłada odnoszenie go tylko do części obszaru posługiwania się przez administrację publiczną prywatnoprawnymi formami działania ${ }^{16}$. W tym ujęciu prawo administracyjne prywatne wyodrębniane jest jako zbiór norm prawnych, w których sprzężenie pierwiastka administracyjnoprawnego i prywatnoprawnego dostrzegalne jest już na etapie tworzenia prawa. Normy zaliczane do prawa administracyjnego prywatnego mają zatem regulować instytucje prawne zespalające ,prawnoprywatne sposoby działania i prawnopubliczne mechanizmy ochrony" ${ }^{\prime 7}$. Ze względu na konieczność efektywnej realizacji imperatywu ochrony konstytucyjnych praw podstawowych za pomocą swoistych publicznoprawnych instrumentó $\mathrm{w}^{18} \mathrm{~W}$ prawie administracyjnym prywatnym unormowania o prywatnoprawnej proweniencji podlegają daleko idącym publicznoprawnym modyfikacjom i uzupełnieniom, odpowiadającym implikacjom wynikającym ze „stałej odpowiedzialności administracyjnej” (permanenter Verwaltungsverantwortung) za ochronę praw podstawowych ${ }^{19}$. W prezentowanym ujęciu poza granicami prawa administracyjnego prywatnego znalazłyby się zatem normy, na podstawie których organy administracji publicznej wykonują zadania administracyjne $\mathrm{w}$ formach prywatnoprawnych, pozbawione odniesienia do swoistych instrumentów ochrony o publicznoprawnym charakterze ${ }^{20}$. W dalszych rozważaniach przyjęte zostanie to właśnie ujęcie prawa administracyjnego prywatnego - w konwencję pojęciową funkcjonującą w polskiej nauce prawa niewątpliwe lepiej wpisuje się odnoszenie nazwy „prawo administracyjne prywatne" do zbioru norm prawnych, nie zaś do zjawiska swoistego stosowania norm.

Wstępne ustalenie obszaru wyodrębniania prawa administracyjnego prywatnego pozwala podjąć rozważania w kwestii zasadności opatrywania relewantnego zbioru norm prawnych nazwą ,prawo administracyjne prywatne”. Rozważania te należy przeprowadzić in abstracto oraz in concreto. Rozważania in abstracto powinny zostać nakierowane na rozstrzygnięcie, czy analizowana nazwa nie stanowi oksymoronu, za sprawą dogmatu o publicznoprawnej przynależności prawa administracyjnego — a zatem czy w prawie administracyjnym można w ogólności

16 H.J. Wolff, O. Bachof, R. Stober, Verwaltungsrecht, t. 1, München 1999, s. 286.

17 E. Schmidt-Aßmann, Ogólne prawo administracyjne jako idea porzadku, s. 368.

18 W kwestii celów i sposobu realizacji ochrony prawnej w sferze prawa administracyjnego prywatnego zob. U. Stelkens, Verwaltungsprivatrecht, Berlin 2005, s. 82-85.

19 H.J. Wolff, O. Bachof, R. Stober, op. cit., s. 310.

20 Może to dotyczyć na przykład sytuacji, w której gmina założyła spółkę akcyjną realizującą na rzecz mieszkańców gminy dostawy prądu na podstawie umów cywilnoprawnych. Sytuacja taka będzie podlegać odniesieniu do prawa administracyjnego prywatnego wyłącznie w pierwszym z przedstawionych ujęć, por. D. Schroeder, op. cit., s. 19. 
wyróżniać substrat publicznoprawny i prywatnoprawny. Rozważania in concreto zostaną poświęcone ustaleniu, czy nazwa „prawo administracyjne prywatne” (w wypadku niestwierdzenia jej oksymoronicznego charakteru) jest właściwym odpowiednikiem niemieckiego terminu Verwaltungsprivatrecht, do którego odnoszą się stanowiska doktryny niemieckiej przytoczone w części drugiej niniejszego artykułu.

Dla dopuszczenia (w ogólności) nazwy „prawo administracyjne prywatne” zasadnicze wydaje się przyjęcie, że twierdzenie o publicznoprawnej przynależności prawa administracyjnego ma walor typologiczny, nie zaś klasyfikacyjny — w tym ujęciu o zaliczaniu prawa administracyjnego do prawa publicznego przesądza przystawalność większości (a nie całości) jego norm do kryteriów (bardzo, zresztą, zróżnicowanych) wyróżniania prawa publicznego. Jak zaznacza K. Opałek, nie sposób wytyczać granicy między prawem publicznym a prawem prywatnym w aspekcie klasyfikacyjnym, czyli aby w obrębie obu członów podziału znalazły się całe gałęzie prawa - w każdej gałęzi znajdują się bowiem normy o charakterze zarówno publicznoprawnym, jak i prywatnoprawnym ${ }^{21}$. Tę samą myśl wyraziście ujmuje rosyjski uczony J.K. Tołstoj, podkreślając, że nie istnieją ,chemicznie czyste" gałęzie prawa, w których znajdowałyby się jednorodne normy prawne, o cechach pozwalających zaliczyć je en bloc wyłącznie do prawa publicznego lub prawa prywatnego 22 . Przykłady regulacji prywatnoprawnych w prawie administracyjnym oraz publicznoprawnych w prawie cywilnym wskazywał H. $\operatorname{Rot}^{23}$, przytaczając, odpowiednio, art. 29 kodeksu postępowania administracyjnego ${ }^{24}$ oraz art. 80 kodeksu cywilnego ${ }^{25}$.

W aspekcie dalszych wywodów prowadzonych w niniejszym opracowaniu godne szczególnego podkreślenia wydaje się, że w prawie administracyjnym stosowane są niekiedy instrumenty prawne zapożyczone z prawa cywilnego, odznaczające się stosunkami prawnymi opartymi na równorzędności stron, powstającymi w rezultacie zgodnych oświadczeń stron, będącymi cechą znamienną prawa prywatnego w myśl teorii podporządkowania ${ }^{26}$. Odnosząc się do cywilnoprawnych inspiracji unormowań prawa administracyjnego, J.S. Langrod wskazywał, że „narodzinom prawa administracyjnego musiało z natury rzeczy towarzyszyć

21 K. Opałek, Problemy metodologiczne nauki prawa, Warszawa 1962, s. 181.

22 J.K. Tołstoj, O priepodowanii grażdanskogo prawa na sowriemiennom etapie, [w:] Priepodowanie grażdanskogo prawa w sowriemiennych usłowiach, red. J.K. Tołstoj, Sankt Pietierburg 1999, s. 43.

${ }^{23}$ H. Rot, Problem dychotomii prawa publicznego i prywatnego, „Przegląd Prawa i Administracji" 7, 1976, s. 23-24.

24 Do 1980 r. art. 29 stanowił, że „strona może działać przez pełnomocnika, chyba że charakter czynności wymaga jej osobistego działania".

25 Do 2010 r. art. 80 stanowił, że, ,jeżeli osoba nie mogąca czytać ma złożyć oświadczenie woli na piśmie, oświadczenie powinno być złożone w formie aktu notarialnego".

26 Zob. S. Fundowicz, Dychotomiczny podział prawa, „Samorząd Terytorialny” 2000, nr 1-2, s. 52-53. 
zaciąganie u prawa cywilnego różnorodnych pożyczek", przy czym pożyczki te polegały często na sięganiu z prawa cywilnego po konstrukcje „ogólno-prawne”, których prawo cywilne „bynajmniej dla siebie nie monopolizuje [...], a tylko jakby je »przechowuje« w rezerwuarze pojęć wykształconych przez siebie i na swój użytek" ${ }^{27}$. Recepcja instytucji o cywilnoprawnej genezie do prawa administracyjnego przybierała jednak postać swoistą, polegającą na ograniczaniu lub wręcz „łamaniu" instytucji prawa cywilnego z uwagi na zachodzącą niekiedy niemożność pozostawienia $\mathrm{w}$ prawie administracyjnym pierwiastka wolności indywidualnej znamionującej regulację cywilnoprawną ${ }^{28}$. Przez wzgląd na powyższe, w prywatnoprawnej części prawa administracyjnego należy sytuować normy prawne kreujące instytucje (instrumenty) zbudowane na fundamencie prywatnoprawnym - przede wszystkim oparte na zasadzie równorzędności i autonomiczności stron stosunków prawnych — poddane jednak modyfikacjom administracyjnoprawnym w stopniu odpowiednio wysokim, że wydają się przystawalne raczej do sfery prawa administracyjnego aniżeli do sfery prawa cywilnego. Do takich instytucji należą niewątpliwie wzmiankowane instytucje zespalające prywatnoprawne sposoby działania i publicznoprawne mechanizmy ochrony - mechanizmy te mają wszak na celu ochronę wyznaczników praworządnego działania administracji publicznej przed ucieczką w znamionowaną pierwiastkiem wolności sferę prawa prywatnego.

Niemiecki termin Verwaltungsprivatrecht, opisujący analizowany zbiór norm prawnych, rozmaicie tłumaczono na język polski - jako prawo cywilno-administracyjne, prawo prywatne administracyjne, administracyjne prawo prywatne, prywatne prawo administracyjne oraz prawo administracyjne prywatne. Podzielając stanowisko P. Steca, wypada negatywnie ustosunkować się do pierwszego z przytoczonych tłumaczeń. Termin ,prawo cywilno-administracyjne” z jednej strony sugeruje, że odnosi się do zbioru norm prawnych postrzeganego jako (hybrydalna) gałąź prawa ${ }^{29}$, co wydaje się próbą usytuowania go na zbyt wysokim szczeblu podziału systemu prawa. Z drugiej strony, przedstawia się jako wyraźne świadectwo rezygnacji z postulatu rozłącznego ujmowania podstawowych gałęzi prawa (takich jak prawo cywilne i prawo administracyjne), który — choć bezsprzecznie trudny do osiągnięcia — nieodmiennie inspiruje do prób wytyczenia granic w strukturze poziomej systemu prawa.

Spośród terminów ujmujących w różnym szyku określenia „prywatne” $\mathrm{i}$, administracyjne" ${ }^{30}$ za najbardziej trafny należy uznać termin „,prawo admini-

27 J.S. Langrod, Instytucje prawa administracyjnego. Zarys części ogólnej, Kraków 2003, s. 71-73, reprint wydania z 1947. Zob. też B. Popowska, Kwalifikacja prawna umowy koncesji; instrument ,mieszany” czy typowy dla realizacji zadań gospodarczych przez administracje publiczna??, [w:] Prawne instrumenty oddziaływania na gospodarke, red. A. Powałowski, Warszawa 2016, s. 83.

28 Z. Duniewska, op. cit., s. 157.

29 P. Stec, op. cit., s. 13.

30 Terminami ,,prawo prywatne administracyjne” i ,administracyjne prawo prywatne” posługiwał się zamiennie A. Wasilewski w przetłumaczonej na język polski pracy E. Schmidta-Aßmanna, 
stracyjne prywatne". Wydaje się to uzasadnione dwiema przesłankami. Po pierwsze, wypada zaznaczyć, że zgodnie z obowiązującą w języku polskim regułą szyku przymiotników wśród dwóch przymiotników następujących po rzeczowniku ważniejszy jest przymiotnik pierwszy. Dlatego też termin ,prawo administracyjne prywatne" w sposób wyraźny sygnalizuje, że odnoszone do niego normy prawne należy postrzegać w pierwszej kolejności jako normy prawa administracyjnego, zaś prywatnoprawny charakter jest ich cechą w tórną. Stanowisko to nawiązuje do obecnej w tradycji nauki prawa administracyjnego teorii bezwzględnej swoistości działalności państwa (władzy publicznej), która — nawet jeżeli wykonywana jest w formach właściwych prawu prywatnemu — nie traci atrybutu władztwa jako cechy znamionującej całość działań administracji ${ }^{31}$. J.S. Langrod, zaznaczając, że „swoistość aktywności państwa występuje zawsze”, wobec czego „nie można żadnego wycinka tej aktywności postawić pojęciowo naprawdę na równi z aktywnością prywatną", wskazał na domniemanie właściwości prawa administracyjnego jako prawa powszechnego dla aktywności państwa ${ }^{32}$. Normy zaliczane do prawa administracyjnego prywatnego $\mathrm{w}$ pierwszym planie winny być więc postrzegane przez pryzmat ich treści (odnoszącej się do działalności państwa), a dopiero $\mathrm{w}$ drugim planie - $\mathrm{z}$ uwzględnieniem wynikającej z norm prywatnoprawnej formy działania. Mówiąc obrazowo, prawo administracyjne prywatne przedstawia się jako prywatnoprawna skorupa wydrążona $\mathrm{z}$ właściwej prawu prywatnemu wewnętrznej zawartości - wolności i autonomii woli ${ }^{33}$, wypełniona zaś materią administracyjnoprawną, inkorporującą prawne determinanty funkcjonowania administracji publicznej.

Ponadto, przyjęcie terminu ,prawo administracyjne prywatne” odzwierciedla dostrzegalną w nauce gradację płaszczyzn porządkowania systemu prawa w strukturze poziomej, zakładającą wyższą doniosłość teoretyczną i praktyczną dzielenia systemu prawa na gałęzie aniżeli ujmowania go w ramach dychotomii prawa publicznego i prawa prywatnego ${ }^{34}$. Choć podział na prawo publiczne i prawo prywatne postrzegany jest przeważnie jako podział ,ponadgałęziowy”35, to jednak — ma-

Ogólne prawo administracyjne jako idea porzadku, s. 368-370. Terminu ,prywatne prawo administracyjne" użyli: K. Nowacki w przetłumaczonej na język polski pracy H. Maurera, op. cit., s. 43; oraz A. Haręża, M. Szydło i W. Szydło, op. cit., s. 12. Termin „,prawo administracyjne prywatne” wykorzystuje J. Zimmermann, Aksjomaty prawa administracyjnego, s. 55; idem, Prawo administracyjne, s. 43.

31 Według J. Starościaka „całość działań administracji nosi znamiona władztwa administracyjnego", idem, [w:] System Prawa Administracyjnego, t. 3, red. T. Rabska, J. Łętowski, Wrocław 1978, s. 167.

32 J.S. Langrod, op. cit., s. 61.

33 Zob. H. Maurer, op. cit., s. 43.

34 Do wyjątków należy stanowisko W. Łączkowskiego opowiadającego się za większą przydatnością podziału prawa na prawo publiczne i prawo prywatne, idem, Ustrojowe podstawy prawa publicznego, [w:] Wspótczesne problemy prawa publicznego, red. S. Fundowicz, Lublin 1999, s. 13.

35 Zob. H. Rot, op. cit., s. 23. 
jąc na względzie „pierwszeństwo” podziału systemu prawa na gałęzie — wydaje się, że dychotomię prawo publiczne-prawo prywatne można sytuować również na szczeblu „podgałęziowym”, w obrębie poszczególnych gałęzi prawa. W tym ujęciu charakter publicznoprawny i prywatnoprawny należałoby przypisywać nie całym gałęziom prawa (co, jak uzasadniano na podstawie stanowisk K. Opałka, J.K. Tołstoja i H. Rota, jest zabiegiem umiarkowanie trafnym), lecz poszczególnym normom zaliczanym do danej gałęzi. W różnych gałęziach prawa proporcje występowania norm publicznoprawnych i prywatnoprawnych przedstawiałyby się w sposób odmienny (co uzasadniałoby ewentualnie zaliczanie gałęzi prawa do prawa publicznego i prawa prywatnego w płaszczyźnie typologicznej) — o ile w prawie administracyjnym i prawie karnym dominują niewątpliwie normy publicznoprawne, o tyle w prawie cywilnym przeważają normy prywatnoprawne. W prawie gospodarczym (jeżeli uznawać je za gałąź prawa) liczebność norm publicznoprawnych i prywatnoprawnych byłaby zapewne zrównoważona. W ramach ,podgałęziowego" ujęcia dychotomii prawo publiczne-prawo prywatne termin ,prawo administracyjne prywatne” wskazywałby wyraźnie na normy prawa administracyjnego, którym przypisuje się — ze względu na przyjęte kryterium lub kryteria rozróżniania prawa publicznego i prawa prywatnego — charakter prywatnoprawny.

\section{IV}

Teoretyczne rozważania dotyczące koncepcji prawa administracyjnego prywatnego wymagają dopełnienia odniesieniem do regulacji prawa pozytywnego, które byłyby przystawalne do abstrakcyjnie wyodrębnionej konstrukcji. Jako wzorcowy, modelowy obszar regulacji prawnej podlegający zaliczeniu do prawa administracyjnego prywatnego przedstawia się prawo zamówień publicznych. Konstrukcja prawa administracyjnego prywatnego wydaje się adekwatną próbą wskazania miejsca prawa zamówień publicznych w systemie prawa, które w nauce jest określane w sposób wysoce różnorodny. Na gruncie stanowisk doktryny wyróżnić można cztery zasadnicze koncepcje postrzegania systemowej przynależności prawa zamówień publicznych. Zgodnie z pierwszą koncepcją, będącą tradycyjnym poglądem nauki niemieckiej ${ }^{36}$, systemową przynależność prawa zamówień publicznych należy rozpatrywać odrębnie w odniesieniu do procedury udzielania zamówienia publicznego i umowy zamówienia publicznego - o ile normy prawne regulujące procedurę stanowią część prawa administracyjnego, o tyle normy dotyczące umowy i jej wykonania wypada sytuować w obrębie prawa prywat-

36 Zob. E. Schmidt-Aßmann, Structures and Functions of Administrative Procedures in German, European and International Law, [w:] Transforming Administrative Procedure, red. J. Barnes, Sevilla 2008, s. 56. 
nego. Druga koncepcja zakłada niezasadność przeprowadzania wewnątrz prawa zamówień publicznych podziału systemowego i określenie prawa zamówień publicznych en bloc jako obszaru mieszanych regulacji prawnych, w którym pierwiastki publicznoprawny i prywatnoprawny przenikają się w sposób trudny do rozgraniczenia ${ }^{37}$. Trzecia i czwarta koncepcja opowiadają się za jednoznacznym usytuowaniem całości prawa zamówień publicznych w ramach gałęziowego lub ponadgałęziowego uporządkowania struktury poziomej systemu prawa - w obrębie prawa administracyjnego (prawa publicznego) ${ }^{38}$ albo też w obrębie prawa cywilnego (prawa prywatnego) ${ }^{39}$, z uwzględnieniem istotnych oddziaływań płynących z kierunku przeciwnej strony podziału systemu prawa.

Stanowisko o postrzeganiu prawa zamówień publicznych jako elementu prawa administracyjnego prywatnego, choć nie było dotychczas formułowane $\mathrm{w}$ doktrynie polskiej, obecne jest w nauce niemieckiej ${ }^{40}$. Wydaje się, że prawo administracyjne prywatne jako odpowiedź na pytanie o systemową przynależność prawa zamówień publicznych tworzy — na wzór Heglowskiej dialektyki — syntezę kształtującą się między przeciwległymi biegunami prawa administracyjnego i prawa prywatnego. Pozwala jednocześnie określić w sposób konkluzywny miejsce w systemie prawa (w strukturze poziomej) prawa zamówień publicznych jako całościowo ujmowanej spójnej wewnętrznie struktury, bez przeprowadzania w jego obrębie sztucznych podziałów systematyzacyjnych.

Prawo zamówień publicznych odpowiada niewątpliwie ukształtowanej w nauce niemieckiej tożsamości prawa administracyjnego prywatnego, określanej prywatnoprawnymi sposobami działania i publicznoprawnymi mechanizmami

37 Zob. między innymi L. Kieres, [w:] System Prawa Administracyjnego, t. 8B. Publiczne prawo gospodarcze, red. J. Grabowski, L. Kieres, A. Walaszek-Pyzioł, Warszawa 2013, s. 838; A. Panasiuk, Czy w Polsce mamy system zamówień publicznych?, [w:] Prawo zamówień publicznych. Stan obecny i kierunki zmian, red. H. Nowicki, P. Nowicki, Wrocław 2013, s. 37, 42. Takie stanowisko zdaje się zajmować R. Szostak, Zakres i struktura prawa zamówień publicznych, „Prawo Zamówień Publicznych” 2013, nr 4, s. 14-17. M. Szydło wskazuje na stosowanie w prawie zamówień publicznych cywilnoprawnej, administracyjnoprawnej i hybrydowej metody regulacji, a także na trudność w zakresie jednoznacznego stwierdzenia publicznoprawnego lub prywatnoprawnego charakteru prawa zamówień publicznych, jako że ,przymiot publiczności lub prywatności przydawany zamówieniom publicznym (oraz przepisom prawa zamówień publicznych) jest kwalifikacją wyłącznie konwencjonalną i opartą w całości na subiektywnie przyjętych kryteriach, zaś poszczególne zamówienia publiczne (oraz przepisy prawa zamówień publicznych) mogą mieć w pewnym zakresie charakter publicznoprawny, zaś w innym zakresie mogą mieć one charakter prywatnoprawny", idem, Prawna koncepcja zamówienia publicznego, Warszawa 2014, s. 215-251, 255-256.

38 Zob. między innymi S. Fundowicz, Miejsce prawa o zamówieniach publicznych w prawie administracyjnym, [w:] XV-lecie systemu zamówień publicznych w Polsce, red. H. Nowicki, J. Sadowy, Toruń-Warszawa 2009, s. 36-47; H. Nowicki, Prawo zamówień publicznych - pojęcie i zakres regulacji, [w:] XV-lecie systemu zamówień publicznych w Polsce, s. 91-93; K. Horubski, Administracyjnoprawne instrumenty realizacji zamówienia publicznego, Warszawa 2013, s. 33-66.

39 Zob. między innymi M. Stachowiak, J. Jerzykowski, Prawo zamówień publicznych, Kraków 2004, s. 15-16.

40 E. Schmidt-Aßmann, Ogólne prawo administracyjne jako idea porządku, s. 174-175. 
ochrony. System zamówień publicznych opiera się na prywatnoprawnych sposobach działania - należy za nie uznać umowę w sprawie zamówienia publicznego (której poświęcono regulację w ramach działu IV $\mathrm{PZP}^{41}$ ) oraz postępowanie o udzielenie zamówienia (do tego odnosi się dział II PZP). Ich prywatnoprawny charakter wynika niezbicie z art. 139 ust. 1 oraz art. 14 ust. 1 PZP, nakazujących stosowanie przepisów kodeksu cywilnego do umów w sprawach zamówień publicznych oraz do czynności podejmowanych przez zamawiającego i wykonawców w postępowaniu o udzielenie zamówienia. Prywatnoprawna (cywilnoprawna) natura zarówno umowy w sprawie zamówienia publicznego ${ }^{42}$, jak i postępowania o udzielenie zamówienia ${ }^{43}$ akcentowana jest także w literaturze. Co do drugiego elementu znamionującego prawo administracyjne prywatne $-\mathrm{z}$ pełnym przekonaniem należy stwierdzić, że prawo zamówień publicznych charakteryzują publicznoprawne mechanizmy ochrony, wśród których należy wskazać kontrolę udzielania zamówień wykonywaną przez Prezesa Urzędu Zamówień Publicznych (regulowaną przepisami zawartymi w rozdziale 3 działu V PZP), a także odwołania wnoszone w postępowaniu o udzielenie zamówienia, rozpoznawane przez Krajową Izbę Odwoławczą (czemu poświęcony został rozdział 2 w dziale VI PZP). Administracyjnoprawny (publicznoprawny) charakter tych mechanizmów ochrony nie budzi wątpliwości w doktrynie. Kontrolę wykonywaną przez Prezesa UZP, z powodu kształtujących się w jej ramach stosunków subordynacji między zamawiającymi a Prezesem UZP oraz usy tuowania Prezesa UZP w strukturze organów administracji publicznej, uznano za ,instytucję publicznoprawną polskiego prawa zamówień" 44 . Ponadto, w odniesieniu do odwołania wskazywano, że „postępowanie odwoławcze w procedurze zamówień publicznych wpisuje się niemal idealnie w ramy kontroli prawidłowości rozstrzygnięć postępowania administracyjnego"45, a co więcej: „trudno sobie wyobrazić, by odwołanie mogło służyć do jakiegokolwiek cywilnoprawnego oświadczenia woli, ponieważ konstrukcja taka nie występuje w prawie cywilnym"46. Elementy owe przemawiają bezsprzecznie za

41 Ustawa z dnia 29 stycznia 2004 r. — Prawo zamówień publicznych (Dz.U. z 2017 r. poz. 1579 ze zm.).

42 Zob. między innymi Z. Gordon, Umowa jako przedmiot $i$ instrument kontroli $w$ systemie zamówień publicznych, [w:] Kontrola zamówień publicznych, red. T. Kocowski, J. Sadowy, Wrocław-Warszawa 2013, s. 234-236; R. Szostak, op. cit., s. 11-12.

43 Zob. między innymi K. Horubski, Publiczno- i prywatnoprawne elementy zamówień publicznych, „Państwo i Prawo” 2009, nr 7, s. 75-76; R. Szostak, op. cit., s. 4-7.

${ }^{44} \mathrm{~K}$. Horubski, Publiczno- i prywatnoprawne elementy zamówień publicznych, s. 78.

45 J. Niczyporuk, Skuteczność postępowania odwoławczego w zamówieniach publicznych, [w:] Zamówienia publiczne jako instrument sprawnego wykorzystania środków unijnych, red. E. Adamowicz, J. Sadowy, Gdańsk-Warszawa 2012, s. 41.

46 T. Kocowski, Administratywizacja przepisów regulujacych postępowanie o udzielenie zamówienia publicznego, [w:] Modernizacja zamówień publicznych. Geneza nowelizacji ustawy Prawo zamówień publicznych z 22 czerwca 2016 roku, red. M. Kania, P. Nowicki, A. Piwowarczyk, Warszawa 2017, s. 62. 
przystawalnością polskiego prawa zamówień publicznych do cech znamiennych prawa administracyjnego prywatnego sformułowanych w nauce niemieckiej.

Niezależnie od inspiracji wynikających z nauki niemieckiej, w nawiązaniu do rozważań w przedmiocie terminu ,prawo administracyjne prywatne”, zawartych w części trzeciej niniejszego artykułu, wypada odnieść się do kwestii postrzegania prawa administracyjnego jako pierwotnej płaszczyzny sytuowania prawa zamówień publicznych w strukturze poziomej systemu prawa. Wydaje się, że do wykazania trafności twierdzenia o pierwotnie administracyjnoprawnym charakterze prawa zamówień publicznych zasadnicze są dwie kategorie warunkujące i kształtujące swoisty reżim prawnej regulacji zamówień publicznych — zadania publiczne i interes publiczny. Przede wszystkim wypada podkreślić nierozdzielny związek wykonywania zamówień publicznych z realizacją zadań publicznych, która przedstawia się jako przesłanka wyodrębnienia instytucji zamówienia publicznego. Powiązanie zamówień publicznych z zadaniami publicznymi może materializować się w postaci bezpośredniej i pośredniej. Wykonywanie zamówień publicznych stanowi bezpośrednią realizację zadania publicznego, gdy świadczenie wykonawcy ,jest ukierunkowane na zaspokojenie potrzeby zamawiającego mającej charakter publiczny i/lub gdy świadczenie to przynosi zamawiającemu bezpośrednie przysporzenie gospodarcze mające charakter publiczny" ${ }^{47}$. Powiązanie pośrednie wystąpi, gdy zamówienie będzie stanowić ,instrument tworzenia materialnych, technicznych, czy organizacyjnych podstaw dla wykonywania przez zamawiających, zadań publicznych, które na nich spoczywająa"48. Następnie należy podkreślić doniosłość interesu publicznego w formowaniu unormowań prawa zamówień publicznych, co przejawia się w okoliczności, że kształt szczegółowych regulacji prawa zamówień publicznych, stanowiących o jego swoistości, warunkowany jest przede wszystkim dążeniem do realizacji interesu publicznego - niewątpliwie „obszar zamówień publicznych »skażony« jest bowiem wszechobecnym interesem publicznym, który ogranicza strony stosunku prawnego"49.

Wyróżnione kategorie zadań publicznych i interesu publicznego zdają się decydować o zasadności sytuowania prawa zamówień publicznych w obrębie prawa administracyjnego na gruncie przedmiotowego nurtu definiowania prawa administracyjnego. Typowe ujęcie prawa administracyjnego w sposób przedmiotowy przedstawia E. Ochendowski, postrzegając prawo administracyjne jako ,gałąź prawa, która odnosi się do administracji publicznej”, i zaznaczając, że ,administracja publiczna stanowi punkt odniesienia dla prawa administracyjnego" ${ }^{\circ 0}$. Administracja publiczna jest zaś pojmowana jako „działalność państwa, której przedmiotem są sprawy administracyjne albo inaczej zadania i kompetencje w zakresie władzy

\footnotetext{
47 M. Szydło, op. cit., s. 194.

48 K. Horubski, Administracyjnoprawne instrumenty realizacji zamówienia publicznego, s. 60.

49 A. Panasiuk, op. cit., s. 41.

50 E. Ochendowski, Prawo administracyjne, Torun 2009, s. 19-20.
} 
wykonawczej"51. Władza wykonawcza opiera się z kolei na „wykonywaniu zadań państwowych mających na celu realizację dobra ogólnego, interesu publicznego"52. Przytoczone definicje wskazują na zadania publiczne i interes publiczny jako wyznaczniki pojęcia prawa administracyjnego (w przedmiotowym nurcie jego definiowania). Uprawnione wydaje się zatem stwierdzenie, że skoro kategorie zadań publicznych i interesu publicznego tworzą fundamentalne przesłanki regulacji prawa zamówień publicznych, prawo zamówień publicznych zawiera się w obrębie prawa administracyjnego, które należy zarazem postrzegać jako pierwotną płaszczyznę sytuowania prawa zamówień publicznych w systemie prawa.

Rozważania nad statusem prawa zamówień publicznych jako części prawa administracyjnego prywatnego są dobrą okazją do wyrażenia poglądu dotyczącego częstego w polskiej nauce przedstawiania prawa zamówień publicznych jako zagadnienia publicznego prawa gospodarczego. Wydaje się, że prawo zamówień publicznych w niskim stopniu przystaje do regulacji stanowiących rdzeń publicznego prawa gospodarczego. Istotą publicznego prawa gospodarczego jest bowiem ograniczanie wolności działalności gospodarczej przedsiębiorców prywatnych, polegające na adresowaniu do nich unormowań zakazujących lub nakazujących podejmowanie pewnych zachowań (zarówno w sferze rzeczywistości konwencjonalnej, jak i w sferze rzeczywistości obiektywnej) w ramach wykonywanej działalności gospodarczej, ewentualnie uzależniających dopuszczalność podjęcia niektórych rodzajów działalności gospodarczej (lub tylko określonych czynności) od uzyskania upoważnienia ze strony organu administracji publicznej — przeważnie w postaci indywidualnego aktu administracyjnego. Tak postrzeganą istotę publicznego prawa gospodarczego oddaje definicja tego działu prawa sformułowana przez Z. Snażyk i A. Szafrańskiego, zgodnie z którą publiczne prawo gospodarcze to „prawo ingerencji państwa w sytuację prawną przedsiębiorcy" 53 . Kanonicznymi materialnoprawnymi zagadnieniami publicznego prawa gospodarczego są zatem kwestie rejestracji przedsiębiorców, koncesji, zezwoleń i działalności regulowanej, działalności gospodarczej podmiotów zagranicznych, obciążeń policyjnych i reglamentacyjnych (w tym ochrony konkurencji), regulacji sektorów infrastrukturalnych. W publicznym prawie gospodarczym mieszczą się też liczne obszary szczegółowe, które obejmują normy prawne kreujące swoiste wymogi i obowiązki w odniesieniu do przedsiębiorców wykonujących działalność gospodarczą w poszczególnych dziedzinach gospodarki — będą to (przykładowo): prawo energetyczne, prawo telekomunikacyjne, prawo transportowe, prawo żywnościowe. Podsumowując — w „klasycznym” publicznym prawie gospodarczym władza publiczna działa w sferze imperium, kreując wzory zachowań oparte na znamieniu władczości; zasadniczą zaś kategorię adresatów norm prawnych tworzą

51 Ibidem, s. 22.

52 B. Banaszak, Konstytucja Rzeczypospolitej Polskiej. Komentarz, Warszawa 2012, s. 108109.

53 Z. Snażyk, A. Szafrański, Publiczne prawo gospodarcze, Warszawa 2013, s. 4. 
przedsiębiorcy prywatni, zobligowani czynić zadość obowiązkom wynikającym z przedmiotowych norm.

W odróżnieniu od „klasycznego” publicznego prawa gospodarczego prawo zamówień publicznych należy odnosić do sfery dominium, w której istotą funkcjonowania organów władzy publicznej jest korzystanie i dysponowanie mieniem uczestniczącym w obrocie cywilnoprawnym na równi z innymi podmiotami ${ }^{54}$. Główny interes publiczny realizowany w ramach prawa zamówień publicznych zasadza się niewątpliwie na dążeniu do racjonalnego wydatkowania środków publicznych ${ }^{55}$, podstawową zaś kategorią adresatów norm prawnych należących do prawa zamówień publicznych nie będą podmioty prywatne, lecz insty tucje zamawiające, zobowiązane do stosowania przepisów ustawy (art. 2 pkt 12, art. 3 ust. 1 PZP). Co istotne, sferą stosunków społecznych normowanych regulacjami prawa zamówień publicznych będzie zatem - jak wskazano - sfera wykonywania zadań publicznych przez liczny zbiór podmiotów odznaczających się pierwiastkiem „publiczności”, nie zaś (jak w wypadku „klasycznego” publicznego prawa gospodarczego) sfera działalności gospodarczej przedsiębiorców prywatnych ${ }^{56}$. Przez wzgląd na przedstawione różnice o charakterze fundamentalnym należy wyrazić sceptyczne stanowisko w przedmiocie ujmowania prawa zamówień publicznych jako zagadnienia publicznego prawa gospodarczego. W przedstawionych rozważaniach starano się wykazać, że bardziej adekwatne byłoby zaliczanie prawa zamówień publicznych do prawa administracyjnego prywatnego.

\section{V}

W rezultacie tych rozważań należy stwierdzić, że termin „prawo administracyjne prywatne" nie powinien być postrzegany jako pojęcie oksymoroniczne, przy czym nie wydaje się również próbą kwestionowania publicznoprawnej tożsamości prawa administracyjnego. Wskazuje jednak na zasadność sytuowania prawa administracyjnego w obrębie prawa publicznego w płaszczyźnie typologicznej, a nie klasyfikacyjnej - w prawie administracyjnym przeważają niewątpliwie normy podlegające zaliczeniu (ze względu na różne kryteria) do prawa publicznego, znajdują się w nim wszak też normy prywatnoprawne. Istotą prawa administracyjnego prywatnego postrzeganego jako zbiór norm prawnych jest zespolenie prywatnoprawnych form działania z publicznoprawnymi mechanizmami ochrony,

54 Zob. uchwała Sądu Najwyższego (siedmiu sędziów) z dnia 21 września 1993 r., sygn. III CZP 72/93, OSNC 1994, nr 3, poz. 49.

55 Tak między innymi M. Płużański, Prawo zamówień publicznych. Komentarz, Warszawa 2009, s. XIII.

56 Według J. Grabowskiego prawo gospodarcze (w ogólności) odnosi się do norm prawnych „regulujących stosunki społeczne, jakie powstają na tle wykonywania działalności gospodarczej lub w związku z jej wykonywaniem”, idem, [w:] System Prawa Administracyjnego, t. 8A. J. Grabowski, L. Kieres, A. Walaszek-Pyzioł, Publiczne prawo gospodarcze, Warszawa 2013, s. 15. 
które gwarantują realizację wyznaczników praworządnego działania administracji publicznej także w zakresie posługiwania się normami prawa prywatnego.

Wydaje się, że na gruncie prawa pozytywnego teoretyczne ramy prawa administracyjnego prywatnego należy wypełniać przede wszystkim normami związanymi z funkcjonowaniem administracji w sferze majątkowej, jak — przykładowo - normami prawa zamówień publicznych, w którym zespolenie prywatnoprawnych form działania z publicznoprawnymi mechanizmami ochrony przedstawia się w sposób wyraźnie widoczny. Warto zaznaczyć, że już w 1974 roku, analizując działalność administracji pod rządem prawa cywilnego w krajach kapitalistycznych, J. Jeżewski wskazywał na tendencję rozszerzania pojęcia prawa administracyjnego na „działania administracji w sferze majątkowej służące realizacji interesów publicznych" 57 . Istnieją pewne podstawy, by za trafne uznać posłużenie się teorią fiskusa (zakładającą rozróżnienie prawa publicznego i prawa prywatnego na podstawie majątku jako przedmiotu stosunków prawnych) do wydzielenia w obrębie prawa administracyjnego norm prywatnoprawnych tworzących prawo administracyjne prywatne. Być może zatem to teoria fiskusa jest instrumentem stworzenia Heglowskiej syntezy w postaci prawa administracyjnego prywatnego z pozornie przeciwstawnych elementów — prawa administracyjnego i prawa prywatnego.

\section{PRIVATE ADMINISTRATIVE LAW. THE PROPOSAL OF A NEW TERM IN THE SCIENCE OF POLISH ADMINISTRATIVE LAW}

Summary

Distinction of the set of norms called "private administrative law" is conditioned by the recognition that the theorem on the public-law affiliation of administrative law is of typological relevance, not of classification relevance - in every branch of law (also in administrative law) it is possible to distinguish, in various proportions, norms of public and private law. The norms of private administrative law set the legal framework for public administration to use forms of activity that traditionally belong to private law in a way that prevents "escape to private law", fusing private-law forms of activity and public-law protective measures. Public procurement law is presented as a model area of legal regulation within the scope of private administrative law.

Keywords: private administrative law, escape to private law, public procurement law

\section{BIBLIOGRAFIA}

Banaszak B., Konstytucja Rzeczypospolitej Polskiej. Komentarz, Warszawa 2012.

Coxo A.R., Direito Administrativo Privado - Contributos para a compreensão do Direito Suis, Lisboa 2016.

57 J. Jeżewski, Administracja pod rządem prawa cywilnego, Wrocław 1974, s. 159. 
Duniewska Z., Prawo administracyjne w systemie prawa, [w:] System Prawa Administracyjnego, t. 1. Instytucje prawa administracyjnego, red. R. Hauser, Z. Niewiadomski, A. Wróbel, Warszawa 2010.

Filipek J., Prawo administracyjne. Instytucje ogólne, cz. 1, Kraków 2003.

Fleiner F., Institutionen des Deutschen Verwaltungsrechts, Tübingen 1928.

Fundowicz S., Dychotomiczny podziat prawa, „Samorząd Terytorialny” 2000, nr 1-2.

Fundowicz S., Miejsce prawa o zamówieniach publicznych w prawie administracyjnym, [w:] XV-lecie systemu zamówień publicznych w Polsce, red. H. Nowicki, J. Sadowy, Toruń-Warszawa 2009.

González-Varas Ibáñez S., El Derecho administrativo privado, Madrid 1996.

Gordon Z., Umowa jako przedmiot i instrument kontroli w systemie zamówień publicznych, [w:] Kontrola zamówień publicznych, red. T. Kocowski, J. Sadowy, Wrocław-Warszawa 2013.

Haręża A., Szydło M., Szydło W., Wspótpraca dla rozwoju regionu pomiędzy jednostkami samorzadu terytorialnego a przedsiębiorcami geologicznymi i górniczymi, Wrocław 2013.

Horubski K., Administracyjnoprawne instrumenty realizacji zamówienia publicznego, Warszawa 2017.

Horubski K., Publiczno- i prywatnoprawne elementy zamówień publicznych, „Państwo i Prawo” 2009, $\mathrm{nr} 7$.

Jeżewski J., Administracja pod rządem prawa cywilnego, Wrocław 1974.

Katz A., Staatsrecht. Grundkurs im öffentlichen Recht, Heidelberg 2010.

Kieres L., Sadowa i pozasadowa ochrona interesu przedsiębiorcy, [w:] System Prawa Administracyjnego, t. 8B. Publiczne prawo gospodarcze, red. J. Grabowski, L. Kieres, A. Walaszek-Pyzioł, Warszawa 2013.

Kocowski T., Administratywizacja przepisów regulujących postępowanie o udzielenie zamówienia publicznego, [w:] Modernizacja zamówień publicznych. Geneza nowelizacji ustawy Prawo zamówień publicznych z 22 czerwca 2016 roku, red. M. Kania, P. Nowicki, A. Piwowarczyk, Warszawa 2017.

Langrod J.S., Instytucje prawa administracyjnego. Zarys części ogólnej, Kraków 2003, reprint wydania z 1947.

Łączkowski W., Ustrojowe podstawy prawa publicznego, [w:] Współczesne problemy prawa publicznego, red. S. Fundowicz, Lublin 1999.

Łętowski J., W sprawie granicy między prawem publicznym a prywatnym, [w:] Prace z prawa cywilnego wydane dla uczczenia pracy naukowej Profesora Józefa Stanisława Piątowskiego, red. B. Kordasiewicz, E. Łętowska, Wrocław 1985.

Maurer H., Ogólne prawo administracyjne, przeł. K. Nowacki, Wrocław 2003.

Niczyporuk J., Skuteczność posteppowania odwoławczego w zamówieniach publicznych, [w:] Zamówienia publiczne jako instrument sprawnego wykorzystania środków unijnych, red. E. Adamowicz, J. Sadowy, Gdańsk-Warszawa 2012.

Nowacki J., Prawo publiczne - prawo prywatne, Katowice 1992.

Nowicki H., Prawo zamówień publicznych — pojęcie i zakres regulacji, [w:] XV-lecie systemu zamówień publicznych w Polsce, red. H. Nowicki, J. Sadowy, Torun-Warszawa 2009.

Ochendowski E., Prawo administracyjne, Torun 2009.

Opałek K., Problemy metodologiczne nauki prawa, Warszawa 1962.

Panasiuk A., Czy w Polsce mamy system zamówień publicznych?, [w:] Prawo zamówień publicznych. Stan obecny i kierunki zmian, red. H. Nowicki, P. Nowicki, Wrocław 2013.

Płużański M., Prawo zamówień publicznych. Komentarz, Warszawa 2009.

Popowska B., Kwalifikacja prawna umowy koncesji; instrument ,, mieszany” czy typowy dla realizacji zadań gospodarczych przez administrację publiczna?, [w:] Prawne instrumenty oddziatywania na gospodarke, red. A. Powałowski, Warszawa 2016.

Prawo administracyjne, red. J. Boć, Wrocław 2010. 
Röder-Persson C., Das Privileg der öffentlichen Grundstückslast im Zwangsversteigerungsgesetz im Lichte der Abschaffung des fiskalischen Konkursprivilegs — zugleich eine Abhandlung über die öffentliche Grundstückslast, Berlin 2004.

Rot H., Problem dychotomii prawa publicznego i prywatnego, „Przegląd Prawa i Administracji” 7, 1976.

Schmidt-Aßmann E., Ogólne prawo administracyjne jako idea porządku. Założenia i zadania tworzenia systemu prawnoadministracyjnego, przeł. A. Wasilewski, Warszawa 2011.

Schmidt-Aßmann E., Structures and Functions of Administrative Procedures in German, European and International Law, [w:] Transforming Administrative Procedure, red. J. Barnes, Sevilla 2008.

Schroeder D., Grundrechte, Heidelberg 2016.

Snażyk Z., Szafrański A., Publiczne prawo gospodarcze, Warszawa 2013.

Stachowiak M., Jerzykowski J., Prawo zamówień publicznych, Kraków 2004.

Stec P., Umowy w administracji. Studium cywilnoprawne, Warszawa 2013.

Stelkens U., Verwaltungsprivatrecht, Berlin 2005.

Stober R., Handbuch des Wirtschaftsverwaltungs- und Umweltrechts, Köln 1989.

System Prawa Administracyjnego, t. 1. Instytucje prawa administracyjnego, red. R. Hauser, Z. Niewiadomski, A. Wróbel, Warszawa 2015.

System prawa administracyjnego, t. 3, red. T. Rabska, J. Łętowski, Wrocław 1978.

System Prawa Administracyjnego, t. 8A. J. Grabowski, L. Kieres, A. Walaszek-Pyzioł, Publiczne prawo gospodarcze, Warszawa 2013.

Szostak R., Zakres i struktura prawa zamówień publicznych, „Prawo Zamówień Publicznych” 2013, nr 4.

Szydło M., Prawna koncepcja zamówienia publicznego, Warszawa 2014.

Tołstoj J.K., O priepodowanii grażdanskogo prawa na sowriemiennom etapie, [w:] Priepodowanie grażdanskogo prawa w sowriemiennych usłowiach, red. J.K. Tołstoj, Sankt Pietierburg 1999.

Wasiliewa A.F., Dogowor w administratiwnom prawie, [w:] Dogowor w publicznom prawie, red. J.W. Gricenko, J.G. Babieluk, Moskwa 2009.

Wipfler J., Leitfaden der Verwaltungslehre, Berlin 1979.

Wolff H.J., Bachof O., Stober R., Verwaltungsrecht, t. 1, München 1999.

Zimmermann J., Aksjomaty prawa administracyjnego, Warszawa 2013.

Zimmermann J., Prawo administracyjne, Warszawa 2014. 